ISLAMIC BANKING Volume 5 Nomor 1 Edisi Agustus 2019 | 39

\title{
ANALISIS KEBANGKRUTAN PADA BANK SYARIAH MANDIRI PERIODE 2014-2017
}

\author{
Fadilla \\ Sekolah Tinggi Ekonomi dan Bisnis Syariah Indo Global Mandiri \\ Email: fadilla@stebisigm.ac.id
}

\begin{abstract}
The perpose of this reseach is to predict the bankcrupty potency from Sharia Mandiri Banking (BSM). The method that used on this paper is modified altman Z score analysis. This research in 2014-2017 periodes. The altman Z score represents by the net working capital to total asset,retaining earning to total asset, earning before interest and tax to total asset, book value equity to book value of debt. The result showed that BSM fit into safe zone in 2014-2017 periods, because the value of $z$ score are 2014 is 6,26, 2015 is 6,2, 2016 is 6,32, 2017 is 6,37. That values bigger than 2,9.
\end{abstract}

Keyword : Sharia Mandiri Banking (BSM),bankcrupty, and Altman Z score

\section{Dasar Pemikiran}

Bank adalah badan usaha yang menghimpun dana dari masyaraakat dalam bentuk simpanan,dan menyalurkannya kepada masyarakat dalam rangka meningkatkan taraf hidup rakyat banyak (Undang-Undang Tentang Perbankan, BAB I Ketentuan Umum Pasal 1 ayat 1). Bank adalah suatu badan usaha yang tugas utamanya sebagai lembaga perantara keuangan (financial intermediaries), yang menyalurkan dana dari pihak yang berkelebihan dana atau kekurangandana (deficit unit) pada waktu yang ditentukan. Bank adalah suatu badan yang bertujuan untukmemuaskan kebutuhan kredit, baik dengan alat-alat pembayarannya sendiri atau dengan uang yang diperolehnya dari orang lain, maupun dengan jalan memperedarkan alat-alat penukar baru berupa uang giral (G.M. Verryn Stuart dalam Swara, Agha, 2012 : 720)

Bank adalah badan yang usaha utamanya menciptakan kredit (Suyatno,1996). Bank adalah suatu jenis lembaga keuangan yang melaksanakan berbagai macam jasa, sepertimemberikan pinjaman, mengedarkan mata uang, pengawasan terhadap mata uang, bertindak sebagaitempat penyimpanan benda-benda berharga, membiayai perusahaan-perusahaan, dan lain-lain (A.Abdurrachman, Ensiklopedia Ekonomi Keuangan dan Perdagangan dalam Swara, Agha, 2012 : 720) 
40 | Fadilla Analisis Kebangkrutan Pada Bank Syariah Mandiri Periode 2014-2017

Secara prinsip ada dua macam jenis Bank yaitu Bank Umum atau yang biasa dikenal dengan Bank Konvensional dan Bank Syariah). Bank umum adalah Bank yang dapat memberikan jasa dalam lalu lintas pembayaran. (Undang-Undang Tentang Perbankan, BAB I Ketentuan Umum Pasal 1 ayat 2 dalam Kasmir, 2014 : 294). Bank syariah adalah lembaga keuangan yang usaha pokoknya memberikan kredit dan jasajasa lain dalam lalu lintas pembayaran serta peredaran uang yang beroperasi disesuaikan dengan prinsip-prinsip syariah(Sudarsono, Heri, 2008 : 27). Di Indonesia sendiri Bank Syariah pertama yang mulai beroperasi adalah Bank Muamalat tepatnya tanggal 1 Mei 1992. Pada waktu Indonesia mengalami krisis moneter tahun 1998, Indonesia mengalami Hyperinflation (inflasi yang sangat berat dimana harga mengalami kenaikan lebih dari 100\%) akibatnya banyak perusahaan yang mengalami kebangkrutan tak terkecuali dunia perbankan. Namun Bank Muamalat Indonesia (BMI) tidak mengalami kebangkrutan sama sekali.

BMI tidak mengalami kebangrutan dikarenakan karena Bank ini menggunakan prinsip syariah. Bank memperoleh dana dari bagi hasil bukan bunga. Dalam sistem bagi hasil jika mengalami keuntungan maka Bank akan mendapat bagian dari keuntungan tersebut sesuai dengan akad (kesepakatan) diawal perjanjian. Jika peminjam dalamhal ini adalah nasabah mengalami kerugian maka Bank tidak akan meminta keuntungan sebagaimana yang dengan kesepakan awal. Pada waktu terjadi hyperinflation pada tahun 1998 BMI tidak mengalami kebangkrutan karena sistem pembayaran yang tidak mengikuti suku bunga yang ada.

Melihat kenyataan ini mulai banyak Bank-bank syariah yang bermunculan. Selain itu masyarakat Indonesia merasa lebih aman menabung di Bank Syariah mengingat mayoritas masyarakat Indonesia beragama Islam. Mulai dari Bank Mandiri yang kemudian membuka anak perusahaan Bank Syariah Mandiri (BSM), Bank Negara Indonesia (BNI) kemudian membuka juga BNI Syariah, Bank Rakyat Indonesia juga membuka BRIS (Bank Rayat Indonesia Syariah), dan masih banyak lagi perusahaan baik Bank maupun non Bank yang kemudian membuka usaha Syariah.

Namun selama beberapa tahun terkahir ini, perkembangan perbankan syariah belum menunjukkan hal yang signifikan. Kementerian Badan Usaha Milik Negara (BUMN) berencana membentuk dua bank syariah dari empat anak usaha bank pelat 
ISLAMIC BANKING Volume 5 Nomor 1 Edisi Agustus 2019 | 41

merah. Semula, kementerian berencana menggabungkan empat bank syariah tersebut menjadi satu megabank syariah.Adapun dua bank syariah yang akan dimerger yakni Bank Syariah Mandiri (BSM) dengan Bank Rakyat Indonesia Syariah (BRIS), sementara Bank Negara Indonesia Syariah (BNI Syariah) digabung dengan Unit Usaha Syariah Bank Tabungan Negara (UUS BTN) (dikutip dari Idealisa Masyrafina Republika 6 Maret 2017) .Peneliti Ekonomi Syariah dari SEBI (School of Islamic Economics), Aziz Setiawan menilai tepat penggabungan tersebut karena bisnis utama yang sama antara BSM dan BRIS, sedangkan BNI Syariah dengan UUS BTN. Menurut Aziz dengan adanya penggabungan keempat Bank ini akan meningkatkan modal. "Dari skala pembiayaan dengan merger tentu kapasitas modal akan membesar dan memberikan leverage untuk menghimpun DPK lebih besar sehingga skala pembiayaan juga lebih besar," ujar Aziz pada Republika.co.id, Senin (6/3).

Selain itu pelopor Bank Syariah di Indonesia Bank Muamalat Indonesia (BMI), juga sedang mengalami masalah keuangan yang cukup pelik. Peneliti Pusat Ekonomi dan Bisnis Syariah Fakultas Ekonomi Bisnis Universitas Indonesia (UI) Yusuf Wibisono menjelaskan masalah yang dihadapi oleh Bank Muamalat terjadi karena rasio pembiayaan bermasalah yang terlalu besar. "Masalah di NPF yang terlampau tinggi, bahkan 2015 pernah NPF lebih dari 7\%. Ini karena adanya masalah pada penyaluran pembiayaan. Kalau terancam bangkrut ya tidak seperti itu juga, karena kuartal 3 tahun lalu sudah lebih baik," kata Yusuf saat dihubungi detikFinance. (Sylke Febrina Laucereno, detik finance)

Penelitian ini bertujuan untuk menganalisis tentang kebangrutan pada Bank-bank Syariah di Indonesia. Adapun objek penelitian ini adalah Bank Syariah Mandiri(BSM). Alasan pemilihan Bank ini karena bank ini merupakan Bank BUMN (BadanUsaha Milik Negara) juga merupakan bank syariah terbesar di Indonesia, serta ada wacana untuk melakukan penggabungan Bank Syariah Mandiri dan BNI Syariah untuk meningkatkan saham Bank syariah yang saat ini masih stagnan 5\%. Oleh sebab itu penelitian ini berjudul Analisis Kebangrutan pada Bank Syariah Mandiri (BSM). 
42 | Fadilla Analisis Kebangkrutan Pada Bank Syariah Mandiri Periode 2014-2017

\section{Penelitian Terdahulu}

Swara, dkk (2012) melakukan penelitian untuk memprediksi kebangrutan pada Bank swasta Nasional. Judul penelitiannya adalah Model Analisis Prediksi Kebangrutan Bank Swata Nasional 2002-2006. Hasil penelitiannya menunjukkan bahwa banyak Bank swasta diprediksi sehat. Hasil penelitian ini berbeda dengan hasil penelitian yang dilakukan oleh Eristy dan Neneng (2015).

Nanda dan Neneng (2015) melakukan penelitian dengan judul Analisis Kebangrutan PT. Bank Central Asia(BCA)\& Bank Negara Indonesia (BNI) Periode 2011-2013. Model Analisis yang digunakan adalah Altman Z Score. Hasil penelitiannya menunjukkan bahwa BCA mengalami kondisi keuangan yang cukup serius.

Nur'aini dan Sharfina (2015) melakukan penelitian yang berjudul Potensi Kebangrutan Pada Sektor Perbankan Syariah Untuk Menghadapi Perubahan Lingkungan Bisnis. Penelitian ini diteliti dengan menggunakan uji Z score Alman yang sudah dimodifikasi dan metode RGEC. Hasil analisisnya kesehatan bank umum syariah menggunakan metode RGEC masuk ke dalam kategori yang "sehat" selama tahun 2010-2014. Model Altman z-score juga menunjukkan bahwa bank umum syariah berada pada keadaan yang safe zone (tidak bangkrut) selama tahun 2010 sampai dengan tahun 2014.(Nur'aini dan Sharfina, $2015: 114$ )

\section{Tinjauan Teori dan Hipotesis}

1. Kebangkrutan dan Fungsi Analisis Kebangrutan

Kebangkrutan merupakan kegagalan perusahaan dalam menjalankan perusahaan untuk menghasilkan laba. Kebangkrutan juga sering disebut likuidasi perusahaan atau penutupan perusahaan atau insolvabilitas. Oleh karena itu prediksi kebangkrutan berfungsi untuk memberikan panduan kepada pihak-pihak yang berkepentingan tentang kinerja keuangan perusahaan apakah akan mengalami kesulitan keuangan atau tidak di masa mendatang. Semakin awal tanda-tanda kebangkrutan diketahui maka akan semakin baik karena manajemen dapat melakukan perbaikan-perbaikan. (Pramata dan Bramantito,2018 : 2). 


\section{Masalah-Masalah Kebangkrutan}

Hanafi dan Halim (2005) juga menyebutkan beberapa masalah yang timbul sehinggadapat mengakibatkan kebangkrutan yaitu, kesulitan keuangan jangka pendek yang berujung menjadi kesulitan yang tidak solvabel. Kesulitan yang tidak solvabel adalah perusahaan mengalami kesulitan dalam membayar hutang karena asset yang terbatas. Elmabrok, et al (2012) berpendapat bahwa kebangkrutan atau kegagalan keuangan terjadi ketika jumlah kewajiban melebihi nilai wajar aset atau ketika kewajiban lancar melebihi aktiva lancar. Kebangkrutan atau kegagalan keuanganyang dialami oleh sebagian besar perusahaan dapat berdampak buruk terhadap perekonomian dunia(June Li, 2012) (Made, $2013: 2$ )

Kalau tidaksolvabel, perusahaan bisa dilikuidasi atau direorganisasi. Likuidasi dipilih apabila nilai likuidasi lebih besar dibandingkan dengan nilai perusahaan. Reorganisasi dipilih kalauperusahaan masih menunujukkan prospek dan dengan demikian nilai perusahaan kalauditeruskan lebih besar dibandingkan nilai perusahaan kalau dilikuidasi. (Arini, $2013: 3$ )

Empat variabel yang menunjukkan perbedaan antara perusahaan yang bangkrut denganyang tidak bangkrut adalah :

a. Tingkat return (rate of return). Perusahaan yang bangkrut mempunyai tingkat returnyang lebih rendah.

b. Penggunaan hutang. Perusahaan yang bangkrut menggunakan hutang yang lebih tinggi.

c. Perlindungan terhadap biaya tetap (Fixed payment coverage). Perusahaan yang bangkrut mempunyai perlindungan terhadap biaya tetap yang lebih kecil.

d. Fluktuasi return saham. Perusahaan yang bangkrut mempunyai rata-rata return yang lebih rendah dan mempunyai fluktuasi return saham yang lebih tinggi.(Arini, $2013: 3)$

Menurut Foster (1986) terdapat beberapa indikator atau sumber informasi mengenai kemungkinan dari kesulitan keuangan:

a) Analisis arus kas untuk periode sekarang dan yang akan datang. 
44 | Fadilla Analisis Kebangkrutan Pada Bank Syariah Mandiri Periode 2014-2017

b) Analisis strategi perusahaan yang mempertimbangkan pesaing potensial, struktur biayarelatif, perluasan rencana dalam industri, kemampuan perusahaan untuk meneruskan kenaikan biaya, kualitas manajemen dan lain sebagainya.

c) Analisis laporan keuangan dari perusahaan serta perbandingannya dengan perusahaan lain. Analisis ini fokus pada suatu variabel keuangan tunggal atau suatu kombinasi dari variabel keuangan.

d) Informasi eksternal seperti return sekuritas dan penilaian obligasi.(Arini, $2013: 3$ )

\section{Bank}

Pengertian bank menurut Taswan (2010:6) yaitu sebuah lembaga perusahaan yang aktivitasnya menghimpun dana berupa giro, deposito tabungan dan simpanan yang lainnya dari pihak yang kelebihan dana (surplus spending unit) kemudian menempatkannya kembali kepada masyarakat yang membutuhkan dana (deficit spending unit) melalui penjualan jasa keuangan yang pada gilirannya dapat meningkatkan kesejahteraan rakyat banyak.( Rofi, $2015: 5$ )

Bank Syariah adalah lembaga keuangan yang usaha pokoknya memberikan kredit dan jasa-jasa lain dalam lalu lintasn pembayaran serta peredaran uang yang beroperasi disesuaikan dengan prinsip-prinsip syariah (Sudarsono, 2008 :27). Gagasan untuk mendirikan bank syariah di Indonesia sebenarnya sudah muncul sejak pertengahan tahun 1970-an. Akhirnya gagasan mengenai bank syariah itu muncul lagi sejak tahun 1988, di saat pemerintah mengeluarkan paket kebijakan Oktober yang berisi liberalisasi industri perbankan. Sehingga padaakhirnya tepatnya tanggal 01 Mei 1992 BankMuamalat Indonesia (BMI) mulai beroperasi (Sudarsono, 2008 :31).

Saat hyper inflation (Inflasi berat dimana harga-harga mengalami kenaikan lebih dari 100\%) melanda Indonesia pada tahun 1998 banyak Bank yang mengalami kebangrutan karena tidak mampu membayar hutang bunga yang melambung tinggi karena inflasi yang tinggi. Namun hanya bank muamalat yang tidak mengalami kebangrutan. Sejak saat itu banyak Bank yang mulai membuka bank syariah, seperti Bank Mandiri yang membuka Bank Syariah Mandiri, BNI yang membuka BNI Syariah, BCA yang membuka BCA Syariah dan masih banyak lagi bank-bank konvensional yang pada akhirnya membuka Bank Syariah. 


\section{Bank Syariah Mandiri}

Pada saat krisis ekonomi tahun 1998, pemerintah memutuskan untuk merestrukturisasi dan merekapitulasi bank-bank di Indonesia. Pemerintah melakukan penggabungan (merger) empat bank yaitu Bank Dagang Negara, Bank Bumi Daya, Bank Exim dan Bapindo dan membentuk PT. Bank Mandiri pada tanggal 31 Juli 1999. Sebagai tindak lanjut dari keputusan merger Bank Mandiri melakukan konsolidasi serta pembentukan perbankan syariah. Selanjutnya melalui surat keputusan gubernur senior Bank Indonesia No.1/24/KEP/BI/1999 disetujui pendirian Bank Syariah Mandiri. Akhirnya pada tanggal 25 Rajab $1420 \mathrm{H}$ atau 01 November 1999.

Produk-produk Bank Syariah Mandiri antara lain BSM tabungan rupiah yaitu tabungan bisa yang dapat diambil sewaktu-waktu. Ada juga BSM cicil emas yaitu produk di mana kita dapat memiliki emas dengan mencici, BSM tabungan mabrur yaitu produk tabungan bagi nasabah yang ingin pergi haji, serta masih banyak lagi tabungan produk-produk yang lain.

Visi Bank syariah mandiri adalah Bank Syariah Terdepan dan Modern. Adapun misinya antara lain:

1. Mewujudkan pertumbuhan dan keuntungan di atas rata-rata industri yang berkesinambungan.

2. Meningkatkan kualitas produk dan layanan berbasis teknologi yang melampaui harapan nasabah.

3. Mengutamakan penghimpunan dana murah dan penyaluran pembiayaan pada segmen ritel.

4. Mengembangkan bisnis atas dasar nilai-nilai syariah universal.

5. Mengembangkan manajemen talenta dan lingkungan kerja yang sehat.

6. Meningkatkan kepedulian terhadap masyarakat dan lingkungan.https://www.syariahmandiri.co.id/tentang-kami/visi-misi, diakses tanggal 15 Agustus 2018)

\section{Metode Penelitian}

Penelitian ini menggunakan Z-Score Alman analisis yang sudah di modifikasi.Altman (1968), merupakan peneliti awal yang mengkaji pemanfaatan 
46 | Fadilla Analisis Kebangkrutan Pada Bank Syariah Mandiri Periode 2014-2017

analisis rasio keuangan sebagai alat untuk memprediksi kebangkrutan perusahaan. Dengan menggunakan analisis diskriminan, fungsi diskriminan akhir yang digunakan untuk memprediksi kebangkrutan perusahaan memasukkan rasio-rasio(Spica,2013: 3).

Fungsi diskriminan $\mathrm{Z}$ yang ditemukan oleh Altman untuk perusahaan perbankan yang telah go public ditentukan dengan menggunakan rumus sebagai berikut (S.Munawir, 2002: 309):

Z-Score $=1,2 \mathrm{X} 1+1,4 \mathrm{X} 2+3,3 \mathrm{X} 3+0,6 \mathrm{X} 4+1,0 \mathrm{X} 5$

Dimana:

$\mathrm{X}_{1}=$ Working Capital / Total Asset

$\mathrm{X}_{2}=$ Retained Earnings / Total Asset

$\mathrm{X}_{3}=$ Earning Before Interest and Taxes/Total Asset

$\mathrm{X}_{4}=$ Book Value of Equity / Book Vaclue of Total Debt

$\mathrm{X}_{5}=$ Sales / Total Asset (Aminah dan Andi Sanjaya, $2013: 5$ )

Dalam analisis Altman z-score modifikasi ini Altman mengeliminasi variabel X5 (sales/total assets), karena rasio ini sangat bervariatif pada industri dengan ukuran aset yang berbeda-beda. Maka, formula persamaan z-score yang telah dimodifikasi oleh Altman dkk menunjukkan fungsi diskriminan sebagai berikut:

$\mathrm{Z}=6.56 \mathrm{X} 1+3.26 \mathrm{X} 2+6.72 \mathrm{X} 3+1.05 \mathrm{X} 4$ (Nur'aini dan Sharfina, $2015: 116$ )

Model Altman Z-Score mengklasifikasikan perusahaan dengan skor $<1,23$ berpotensi untuk mengalami kebangkrutan. Skor 1,23 - 2,90 diklasifikasikan sebagai grey area, sedangkan perusahaan dengan skor $>2,90$ diklasifikasikan sebagai perusahaan yang tidak berpotensi mengalami kebangkrutan (Made, $2013: 6$ )

Jenis Data dan Sampel Penelitian

Data yang digunakan dalam penelitian ini adalah sekunder. Data sekunder adalah data yang diperoleh dari laporan yang dipublikasikan oleh lembaga pengumpulan data. Data diperoleh dari https://www.syariahmandiri.co.id.Adapun objek dalam penelitian ini Bank Syariah Mandiri, dimana periode penelitian adalah tahun 20142017. 
Definisi Operasional Variabel

Peneliti akan menejelaskan definisi setiap variabel dalam penelitian ini. Adapun variabel yang akan diteliti berserta dengan fungsi dan rumusnya akan peneliti jelaskan dalam Tabel di bawah ini

Tabel 1.1.

Definisi Operasional Variabel

\begin{tabular}{|c|c|c|}
\hline Variabel & Konsep Variabel & Proxi \\
\hline X1(WCTA) & $\begin{array}{l}\text { Modal kerja merupakan Menurut J. Fred Westondan } \\
\text { Thomas E Copeland, modal kerja adalah selisih antara } \\
\text { aktiva lancar dan hutang lancar. Aktiva total } \\
\text { merupakan total dari seluruh kekayaan perusahaan. } \\
\text { Pada penelitian ini modal kerja di bandingkan dengan } \\
\text { seluruh aktiva }\end{array}$ & $\frac{\text { Modal Kerja }}{\text { Total Aktiva }}$ \\
\hline $\begin{array}{c}\text { X2 } \\
\text { (RETA) }\end{array}$ & $\begin{array}{l}\text { Laba ditahan merupakan laba yang tidak dibagikan } \\
\text { kepada pemegang saham karena dananya akan } \\
\text { digunakan untuk operasional perusahaan. Pada } \\
\text { penelitian ini laba ditahan bandingkan dengan seluruh } \\
\text { aktiva. }\end{array}$ & $\frac{\text { laba ditahan }}{\text { Total Asset }}$ \\
\hline $\begin{array}{l}\text { X3 } \\
\text { (EBITA) }\end{array}$ & $\begin{array}{l}\text { EBIT (Earning before interest dan tax) adalah laba } \\
\text { kotor yang dimana laba ini belum dikurangi dengan } \\
\text { bunga dan pajak.Pada penelitian ini EBIT bandingkan } \\
\text { dengan seluruh aktiva. }\end{array}$ & $\frac{E B I T}{\text { Total Asset }}$ \\
\hline $\begin{array}{l}\text { X4 } \\
\text { (BVEBVD) }\end{array}$ & $\begin{array}{l}\text { Nilai pada modal merupakan harga saham yang bisa } \\
\text { dijual dibagikan dengan nominalsaham perlembar. } \\
\text { Nilai ini kemudian dibandingkan dengan total hutang. }\end{array}$ & $\frac{\text { Nilai pasar mod }}{\text { Total hutang }}$ \\
\hline
\end{tabular}

\section{Pembahasan}

1. Hasil Analisis dan Pembahasan

Penelitian ini menggunakan analisis $Z$ Score Altman yang sudahn dimodifikasi.Variabel yang akan diuji ada 4 (empat) yaitu WCTA, RETA, EBITA, 
48 | Fadilla Analisis Kebangkrutan Pada Bank Syariah Mandiri Periode 2014-2017

BVEBVD. Adapun tahun penelitian yaitu 2014-2018. Hasilnya terdapat di tabel di bawah ini

Tabel 1.2.

Nilai Variabel Z Score yang dimodifikasi

\begin{tabular}{|c|c|c|c|c|}
\hline Tahun & WCTA & RETA & EBITA & BVEBVD \\
\hline 2014 & $\mathbf{0 , 9 5}$ & $\mathbf{0 , 0 0 0 9 1 4}$ & $\mathbf{( 0 , 0 0 0 0 3 5 )}$ & $\mathbf{0 , 0 0 0 5 4 4}$ \\
\hline 2015 & $\mathbf{0 , 9 3 6}$ & $\mathbf{0 , 0 0 0 7 7 5 6}$ & $\mathbf{0 , 0 0 5 4 5}$ & $\mathbf{0 , 0 0 5 2 6}$ \\
\hline 2016 & $\mathbf{0 , 9 5}$ & $\mathbf{0 , 0 0 0 9 1}$ & $\mathbf{0 , 0 0 5 6}$ & $\mathbf{0 , 0 4 4 5 1}$ \\
\hline 2017 & $\mathbf{0 , 9 6}$ & $\mathbf{0 , 0 0 1 0 2 5}$ & $\mathbf{0 , 0 0 5 5}$ & $\mathbf{0 , 0 3 6}$ \\
\hline
\end{tabular}

Sumber data sekunder yang diolah

Pada tabel variabel Z Score di atas dapat disimpulkan bahwa nilai Working Capital to Total Assets (WCTA). Semakin tinggi nilai rasio ini menunjukkan bank umum syariah semakin baik bank syariah menghasilkan modal kerja bersih yang berakibat semakin tinggi pula tingkat likuiditas bank tersebut (Nur'aini dan Sharfina, 2015 : 27). Dari data di atas terlihat bahwa tahun 2014-2017 BSM memiliki likuiditas yang sangat baik dengan rata-rata nilaiWCTA di atas 0,95 . Tahun 2014 bernilai 0,95 ini berarti setiap pemakaian Rp. 1 akan mengahasilkan modal bersih sebesar 0,95. Tahun 2015 WCTA bernilai 0,936ini berarti setiap pemakaian Rp. 1 akan mengahasilkan modal bersih sebesar 0,936. Pada tahun 2016 0,95 ini menunjukkan setiap pemakaian Rp. 1 akan mengahasilkan modal bersih sebesar 0,95. Terakhir pada tahun 2017 bernilai 0,96 ini berarti setiap pemakaian Rp. 1 akan mengahasilkan modal bersih sebesar 0,96.

Nilai rasio retained earnings to total assets (RETA) yang tertinggi dimiliki oleh Bank menunjukkan kemampuan Bank menghasilkan laba ditahan dari aktiva yang dimilikinya. Pada tahun 2014 RETA BSM bernilai 0,000914 yang berarti kemampuan BSM menghasilkan laba ditahan dari setiap pemakaian sebesar Rp. 1 Aktiva adalah sebesar 0,000914. RETA BSM menurun pada tahun 2015 yaitu sebesar 0,000775 yang berarti pada tahun 2015 dari setiap aktiva sebesar Rp. 1 yang terpakai BSM hanya dapat menghasilkan laba ditahan sebesar 0,000775. Pada tahun 2016 RETA BSM kembali mengalami peningkatan menjasi 0,00091 dan semakin meningkat pada tahun 2017 menjadi 0,001025. Ini berarti kemampuan Bank menghasilkan laba ditahan dari setiap Rp.1 aktiva yang dimiliki pada tahun 2016 adalah 0,00091 dan tahun 2017 menjadi 0,001025 . 
ISLAMIC BANKING Volume 5 Nomor 1 Edisi Agustus 2019 | 49

EBITA merupakan earning before interest and tax dari laporan keuangan BSM merupakan laba sebelum zakat dan pajak penghasilan dari aktiva yang dimilikinya. EBITA BSM menunjukkan pada tahun 2014 mengalami kerugian sebanyak 0,000035. Keadaan mulai berubah tahun 2015 EBITA BSM naik dengan mengalami keuntungan sebanyak 0,0054, dan naik kembali pada tahun 2016 menjadi 0,0056 dan tahun 2017 menjadi 0,0055.

Bank Syariah Mandiri memiliki nilai Book Value of Debtyang menurun setiap tahunnya. Book Value of Debt menunjukkan nilai hutang yang merupakan kewajiban dari perusahaan dalam hal ini Bank Syariah Mandiri (BSM) setiap tahun untuk memenuhinya. Jika nilai ini menurutn atau kecil maka hal itu menunjukkan posisi keuangan perusahaan dalam keadaan baik. Hal ini yang terjadi pada BSM nilaiBook Value of DebtPada tahun 2014 adalah 0,00054, nilai ini menurun pada tahun 2015 menjadi 0,00526, kembali menurun tahun 2016 menjadi 0,04451 dan tahun 2017 menjadi 0,036. Angka ini menunjukkan bahwa BSM memiliki bahwa secara keuangan BSM memiliki kemampuan untuk membayar hutang atau kewajibannya.

Tabel 1.3.

Perhitungan Z Score

\begin{tabular}{|l|l|l|l|l|l|l|}
\hline $\begin{array}{l}\mathbf{N} \\
\text { o }\end{array}$ & Tahun & $\mathbf{6 , 5 6}(\mathbf{X 1})$ & $\mathbf{3 , 2 3}(\mathbf{X 2})$ & $\mathbf{6 , 7 2}(\mathbf{X 3 )}$ & $\mathbf{1 . 0 5}(\mathbf{X 4 )}$ & $\begin{array}{l}\text { Z } \\
\text { Score }\end{array}$ \\
\hline 1 & 2014 & $\mathbf{6 , 2 3 2}$ & $\mathbf{0 , 0 2 9}$ & $\mathbf{- 0 , 0 0 0 2 3 5}$ & $\mathbf{0 , 0 0 0 6 0 5}$ & $\mathbf{6 , 2 6}$ \\
\hline 2 & 2015 & $\mathbf{6 , 1 4 0 1 6}$ & $\mathbf{0 , 0 2 5}$ & $\mathbf{0 , 0 3 6 6}$ & $\mathbf{0 , 0 0 5 3}$ & $\mathbf{6 , 2 0 2}$ \\
\hline 3 & 2016 & $\mathbf{6 , 2 6}$ & $\mathbf{0 , 0 0 2 9 6}$ & $\mathbf{0 , 0 0 3 7 6}$ & $\mathbf{0 , 0 4 6 7}$ & $\mathbf{6 , 3 2 3}$ \\
\hline 4 & 2017 & $\mathbf{5 , 5 7 6}$ & $\mathbf{0 , 0 3 6}$ & $\mathbf{0 , 0 3 6}$ & $\mathbf{0 , 0 3 7}$ & $\mathbf{6 , 3 7 3}$ \\
\hline
\end{tabular}

Dari Tabel 1.3. di atas dapat diketahui bahwa nilai Z Score nya bernilai di atas 6 . Nilai ini lebih besar dari >2,9. Dimana persahaan dinyatakan sehat jika nilai Z Score> 2,9, ini berarti Bank Syariah Mandiri (BSM) dalam keadaaan yang sehat secara keuangan dan tidak terancam bangkrut.

\section{Simpulan}


50 | Fadilla Analisis Kebangkrutan Pada Bank Syariah Mandiri Periode 2014-2017

Hasil penelitian menunjukkan bahwa kondisi keuangan Bank Syariah Mandiri (BSM) dalam keadaaan yang sehat secara keuangan dan tidak terancam bangkrut. Ini terbukti dari nilai Z score pada tahun 2014 bernilai 6,26 cenderung stabil pada 3(tiga) tahun selanjutnya. nilai 6,26 lebih dari 2,9 yang dimana jika $Z$ score 2,9 ini menunjukkan perusahaan dalam keadaan yang sehat.

\section{Saran}

Dari penelitian ini diharapkan bahwa Bank Syariah Mandiri (BSM) dapat terus meningkatkan nilai working capital dengan mempersiapkan aktiva lancar yang mempuni agar dapat mempertahankan kestabilan keuangan BSM sendiri. Jika memungkinkan juga lebih banyak lagi meningkatkan keuntungan yang mungkin akan didapatkan, sehingga tidak perlu berhutang untuk menjalankan operasional perusahaannya. 
ISLAMIC BANKING Volume 5 Nomor 1 Edisi Agustus $2019 \mid 51$

\section{DAFTAR PUSTAKA}

Aminah dan Andi Sanjaya. 2013. Analisis Kebangkrutan pada Perusahaan Perbankan di Indonesia Periode 2001-2012 (Dengan Menggunakan Model AltmanZ-Score). Universitas Bandar Lampung.

Arini, Sopiyah dan Triyonowati. 2013. Analisis Z-Score Untuk Memprediksi Kebangrutan Pada Perusahaan Farmasi di Indonesia. Jurnal Ilmu \& Riset Manajemen Vol. 2 No. 11.

Fadilla dan Havis Aravik, "Pandangan Islam dan Pengaruh Kurs, BI Rate Terhadap Inflasi”, Jurnal Ecoment Global, Volume 3, Nomor 2, Agustus 2018.

Kasmir. 2014. Dasar- Dasar Perbankan. PT. Raja Grafindo Persada : Jakarta

Made, Ni Evi Dwi Prihatini dan Maria M. Ratna Sari. 2013. Prediksi Kebangrutan dengan Model Grover, Altman Z Score, Sprigate, Z Mijeski pada Perusahaan Food and Beverage. E. Jurnal Akuntansi Universitas Udayana Vol. 5 No.3

Nanda, Eristy dan Neneng Susanti. 2015. Analisis Kebangrutan PT. Bank Central Asia(BCA) \& Bank Negara Indonesia (BNI) Periode 2011-2013. Jurnal Akuntansi Bisnis dan Ekonomi.Vol.1 No.2.

Nur'aini, Dwi Ihsan dan Sharfina Putri Kartika. 2015. Potensi Kebangkrutan Pada Perbankan Syariah Untuk Menghadapi Perubahan Lingkungan Bisnis. Etikonomi. Vol. 4 No.2.

Pratama, Fajar dan Bramantiyo Eko Putro. 2018. Analisis Model Prediksi Kebangkrutan Industri Garmen dengan Menggunakan Metode Alman Z-Score. Jurnal Media Teknik \& Sistem Indutri. Vo. 1

Spica, Almilia dan Kristijadi. 2003. Analisis Rasio Keuangan Untuk Memprediksi Financial Distress Perusahaan Manufactur yang Terdaftar di Bursa Efek Jakarta (BEJ). JAAI Vol.7 No.2

Rofi, Aditya Rahmawan. 2015. Analisis Potensi Kebangrutan Pada Bank Negara Indonesia, Tbk. Skripsi. Fakultas Ekonomi \& Bisnis Universitas Muhammadiyah Surakarta.

Swara, Agha Ghanesa, Tpmy G. Soemapradja, Darma, Desmiar. 2012. Model Analisis Prediksi Kebangrutan Bank Swata Nasional 2002-2006. Binus Business Review.Vol.3 No. 2.

Sudarsono, Heri. 2008. Bank dan Lembaga Keuangan Syariah Deskripsi dan Ilustrasi. Edisi Ketiga. EKONISIA : Yogyakarta

http://republika.co.id/berita/ekonomi/syariahekonomi/17/03/06/ome40g382-banksyariah-bumn-akan-digabung-ini-manfaatnya, diakses tangaal 18 Mei 2018.

https://finance.detik.com/moneter/d-3879581/bank-muamalat-terancam-bangkrut-inikata-pengamat, diakses tanggal 16 Maret 2018 
52 | Fadilla Analisis Kebangkrutan Pada Bank Syariah Mandiri Periode 2014-2017

https://www.syariahmandiri.co.id/tentang-kami/visi-misi, diakses tanggal 15 Agustus 2018.

https://www.syariahmandiri.co.id/consumer-banking/jasa-produk/bsm-net-banking, diakses tanggal 15 Agustus 2018.

https://www.syariahmandiri.co.id/assets/pdf/laporan.../AR-BSM-2016-Lap

Keuangan.pdf, diakses tanggal 9 Agustus 2018. 